УДК 340: 342.25

DOI https://doi.org/10.32844/2618-1258.2019.3-2.8

РОГОВЕНКО О.В.

\title{
ДО ПИТАННЯ ПРО ПОСАДОВІ ОБОВ'ЯЗКИ СТАРОСТИ
}

Для управління суттєвою часткою суспільних прав у селі або селищі, посилення самоорганізації, самоуправління, мотивації громад до саморозвитку на основі ефективного використання власних можливостей запроваджено нову посадову особу місцевого самоврядування - старосту, яким має бути особа, що обирається мешканцями села і якому невеликі громади довіряють ведення своїх справ, прийняття управлінських рішень. Здійснення аналізу правового статусу старости $€$ метою даної публікації.

Встановлено, що староста $є$ виборною посадовою особою місцевого самоврядування, що обирається жителями села, селища (сіл, селищ), розташованого на території відповідного старостинського округу, на основі загального, рівного, прямого виборчого права шляхом таємного голосування в порядку, визначеному законом, і здійснює свої повноваження на постійній основі. Повноваження старости починаються з моменту складення ним присяги на пленарному засіданні відповідної сільської, селищної, міської ради. Строк повноважень старости, обраного на чергових виборах, становить п’ять років, крім випадків дострокового припинення його повноважень. Старости формують окремий орган громади - раду старост, що $\epsilon$ допоміжним, дорадчим органом.

Староста - це лідер, якому громада села висловила підтримку, нова посадова особа місцевого самоврядування, нова інституція, створена для того, щоб інтереси всіх жителів сіл в об'єднаних територіальних громадах були належним чином представлені. 3 метою оперативного реагування на соціальні та інші проблеми мешканців, задоволення їх потреб посада старости не просто запроваджена діяльність цих посадовців набирає оберти.

Аргументовано, що в загальному порядку для кандидатів на посаду старости не передбачено наявності спеціальної освіти або складання іспиту зі знання основ місцевого самоврядування, наявності практичного досвіду роботи на державній службі або на службі в органах місцевого самоврядування. Відсутні і вимоги до кандидатів щодо граничного віку та обов'язкового проживання на території територіальної громади.

Ключові слова: місиеве самоврядування, територіальна громада, староста, рада старост, старостинський округ.

Managing a significant share of public rights in a village or village, strengthening self-organization, self-government, motivating communities to self-develop through the effective use of their own capabilities, a new local government official has been introduced - an elder, who should be a person elected by the residents of the village and to whom the small communities affairs, making management decisions. An analysis of the legal status of old age is the purpose of this publication.

It is established that the headman is an elected official of local self-government, elected by the residents of a village, village (s, settlements) located in the territory of the respective district, on the basis of universal, equal, direct suffrage by secret ballot in the manner prescribed by law, and exercises their authority on an ongoing basis. The powers of the elder start from the moment of his taking the oath at the plenary meeting of the respective village, settlement, city council. The term of office of the old-age elected in the next election shall be five years, except in the case of early termination of his / her

(C) РОГОВЕНКО О.В. - кандидат юридичних наук, доцент, доцент кафедри адміністративного та інформаційного права (Сумський національний аграрний університет) 
term of office. The Elders form a separate community body, the Elders Council, which is an ancillary, advisory body.

The elder is a leader to whom the village community has expressed support, a new local government official, a new institution created to ensure that the interests of all villagers in the united territorial communities are properly represented. In order to respond promptly to the social and other problems of the residents, meet their needs, the position of old age is not simply introduced, the activity of these officials is gaining momentum.

It is argued that, as a general rule, candidates for the old age do not have special education or an examination for knowledge of the basics of local self-government, practical experience in public service or in the service of local self-government bodies. There are also no requirements for candidates for age limits and compulsory residency in the territorial community.

Key words: local self-government, territorial community, head of state, council of heads, district of stastin.

Вступ. Новелою у чинному законодавстві є посада старости. Згідно з Європейською Хартією місцевого самоврядування, яка $\epsilon$ частиною законодавства України, місцеве самоврядування - це «право і спроможність органів місцевого самоврядування ... здійснювати регулювання і управління суттєвою часткою суспільних прав, які належать до їхньої компетенції, в інтересах місцевого населення». Саме з метою управління суттєвою часткою суспільних прав в селі або селищі, посилення самоорганізації, самоуправління, мотивації локальних людських спільнот (громад) до саморозвитку на основі ефективного використання власних можливостей запроваджено нову посадову особу місцевого самоврядування - старосту, яким має бути особа, що обирається мешканцями села і якому невеликі громади довіряють ведення своїх справ, прийняття управлінських рішень. Крім того, староста є посадовою особою місцевого самоврядування в селі або селищі, які разом з іншими населеними пунктами добровільно об'єднуються в одну територіальну громаду (про це ми зазначимо нижче). Саме староста постійно перебуває на території села/ селища (має робоче місце на території села), для мешканців територіальної громади $є$ зрозумілим графік роботи старости та прийому громадян. Староста організовує різні заходи в селі/селищі, знає проблеми села/селища та сприяє їх вирішенню самостійно або/та разом із відповідними органами та посадовими особами, працює із громадськими об'єднаннями, реалізовує проекти благоустрою села/селища тощо. 3 огляду на це дослідження правового статусу старости $є$ актуальним як для науковців, так і для юристів-практиків.

Постановка завдання. Аналіз правового статусу старости, його посадових обов'язків $є$ метою даної публікації.

Аналіз останніх досліджень і публікацій, в яких започатковано розв'язання даної проблеми, виділення невирішених раніше частин загальної проблеми. Над проблемами дослідження правового статусу старости працювали Я. Брусенцова, І. Дробуш, Ю. Ганущак, В. Коновалов, В.Куйбіда, В. Куліченко, О. Данильян, О. Кресін та багато інших науковців. У представленій роботі викладено авторське бачення методологічного підходу, під кутом використанням якого для науковців відкриваються нові можливості для проведення дослідження.

Результати дослідження. Свого часу Кабінет Міністрів України запропонував Верховній Раді України запровадити посаду сільського старости [1], якого призначатиме виконавчий орган об'єднаної територіальної громади. Виникла дискусія, з'явились сумніви. Як зазначає I. Дробуш, існували перестороги, що «запровадження інституту старост негативно впливатиме на раціональність структури виконавчих органів громади, обтяжуючи ії зайвими дорадчими органами. Так, наприклад, рада старост дублюватиме громадську раду та інші органи громади. ... Оскільки в Україні і так украй напружена ситуація та щоб ще більше ії дестабілізувати навмисно серед самої територіальної громади проводяться паралелі щодо існування посади старости в сучасний період і період нацистської окупації» [2]. Тим не менше, були й протилежні судження та, навіть більше того, розроблювалися різні варіанти функціонування цієї посади.

Зауважимо, що в межах швейцарсько-українського проекту «Підтримка децентралізації в Україні - DESPRO» Ю. Ганущак зробив такі узагальнення та пропозиції до питання запровадження посади старости. Так, автор запропонував: «Залежно від розміру поселення та кількості мешканців повинно розглядатися питання відшкодування старостам за виконання їхніх повноважень. На 
повну зайнятість найімовірніше можуть претендувати старости поселень понад 1000 мешканців. У менших поселеннях вони мають отримувати компенсацію за витрачений для публічних справ час. За своїм статусом староста повинен мати певний вплив на рішення органів громади. $€$ три варіанти реалізації такої вимоги: 1) староста є депутатом ради громади. При цьому половина ради формується зі старост, друга - пропорційно до кількості населення. Недоліком вказаної схеми є те, що в деяких громадах може бути дуже багато поселень, і рада буде надто громіздкою. Крім цього, старости отримують відшкодування з бюджету громади, тому певною мірою залежні від іії виконавчих органів, зокрема голови. Суміщення їхніх функцій із представницьким мандатом $€$ конфліктом інтересів, що суперечить теорії організації публічної влади; 2) староста є членом виконавчого органу громади. Недоліком $є$ те, що виконавчий комітет здебільшого формується як функціональний орган і складається із представників різних галузей. Інший недолік аналогічний попередньому варіанту - громіздкість виконкому за наявності багатьох поселень; 3) старости поселень формують окремий орган громади - рада старост. Недоліком $€$ те, що старости представляють різну кількість населення, що може викликати тертя та внутрішню напругу. До того ж з'являється спокуса штучно дробити поселення для отримання представництва. Пом'якшенням цього фактору може бути встановлення мінімальної кількості населення в поселенні для обрання там старости. Менші поселення (можна називати їх хуторами, хоча це не повинно регламентуватись) представлені старостами сусідніх більших поселень. Старости представляють фактично не тільки населення поселень, але й територію. Складнощі полягають у новизні і незвичності такої форми організації. Тому повноваження цієї інституції повинні бути ретельно виписані. Цей варіант розглядається як основний. Рада старост є допоміжним, дорадчим органом при голові ради, оскільки Конституція України не передбачає двопалатності місцевих рад. Однак необхідно встановити певний перелік питань, які $є$ обов'язковими до розгляду радою старост перед винесенням їх на сесію ради громади. Це повинні бути питання, що безпосередньо стосуються територій, поселень, передусім тих, що не $є$ центральними. Це питання управління землею, бюджет та питання проектів соціально-економічного розвитку. Хоча рішення ради старост мають рекомендаційний характер, вони суттєво впливатимуть на позицію депутатів та голови громади. Очевидно, що якщо рішення ради старост та ради громади будуть істотно відрізнятись, це буде важливим сигналом для голови громади для накладення вето на рішення ради громади. Оскільки міські та сільські громади відрізняються, вплив старост теж повинен бути різним. Можливо, слід застосовувати різні схеми організації роботи та статусу старост у громаді. Так, ряд поселень, що злились із містом і за своїм типом забудови є фактично селами, можуть претендувати на представництво в раді старост. Такі можливості потрібно передбачати у статуті громади. Законом слід зафіксувати лише умови, за яких обрання старост є обов'язковим» $[3$, c. 60].

Нині посада старости стала реальною в системі місцевого самоврядування. Староста - це лідер, якому громада села висловила підтримку. Він - нова посадова особа місцевого самоврядування, нова інституція, створена для того, щоб інтереси всіх жителів сіл в об'єднаних територіальних громадах були належним чином представлені [4]. 3 метою оперативного реагування на соціальні та інші проблеми мешканців, задоволення їхніх потреб посада старости не просто запроваджена - діяльність цих посадовців набирає оберти.

Слід зауважити, що реформа місцевого самоврядування, об'єднання територіальних громад викликали застереження і з боку районної влади - районних рад і районних державних адміністрацій, які побоювались втратити ресурси та повноваження, адже, як зазначають експерти [5], реформа може загрожувати їхнім посадам. Позитивні фінансові результати діяльності об'єднаних територіальних громад (далі - ОТГ) поступово змінюють ситуацію на краще. Але прогалини в законодавстві, комунікації, доступі до інформації уповільнюють процес реформи. Допомогти невеликим громадам у представленні їхніх інтересів та взаємодії з районного владою, фінансуванні потреб мешканців має запроваджена посада старости.

Відповідно до ст. $14^{-1}$ Закону України «Про місцеве самоврядування в Україні» староста $є$ виборною посадовою особою місцевого самоврядування. Староста обирається жителями села, селища (сіл, селищ), розташованого на території відповідного старостинського округу, на основі загального, рівного, прямого виборчого права шляхом таємного голосування в порядку, визначеному законом, і здійснює свої повноваження на постійній основі. Повноваження старости починаються з моменту складення ним присяги відповідно до Закону України «Про службу в органах місцевого самоврядування» на пленарному засіданні відповідної сільської, селищної, міської ради, на якому відповідною територіальною виборчою комісією були оголошені рішення щодо його обрання та реєстрації. Строк повноважень старости, обраного на чергових виборах, 
становить п'ять років, крім випадків дострокового припинення його повноважень 3 підстав і в порядку, визначених цим Законом.

Староста $є$ членом виконавчого комітету сільської, селищної, міської ради за посадою. 3 огляду на це для ефективної реалізації повноважень старости як члена виконкому важливе значення має якісний Регламент цього виконавчого органу, де слід детально виписати процедурні моменти участі старости в його роботі та можливості прийняття спільних рішень.

Як член виконавчого комітету староста має право вносити пропозиції, зауваження з питань, що стосуються села, селища, інтереси якого він представляє, в галузях повноважень виконавчого комітету місцевої ради, зокрема в таких сферах: соціально-економічного і культурного розвитку, планування та обліку; бюджету, фінансів і цін; управління комунальною власністю; житлово-комунального господарства, побутового, торговельного обслуговування, громадського харчування, транспорту і зв'язку; будівництва; освіти, охорони здоров'я, культури, фізкультури і спорту; регулювання земельних відносин та охорони навколишнього природного середовища; соціального захисту населення; зовнішньоекономічної діяльності; оборонної роботи; адміністративно-територіального устрою; забезпечення законності, правопорядку, охорони прав, свобод і законних інтересів громадян; надання безоплатної первинної правової допомоги; відзначення державними нагородами України [5].

Староста не може мати інший представницький мандат, поєднувати свою службову діяльність 3 іншою посадою, зокрема й на громадських засадах, займатися іншою оплачуваною (крім викладацької, наукової і творчої діяльності, медичної практики, інструкторської та суддівської практики зі спорту) або підприємницькою діяльністю. Порядок організації роботи старости визначається цим та іншими законами, а також Положенням про старосту, затвердженим сільською, селищною, міською радою. Діяльність старости села (селища, міста) фінансується за рахунок бюджету сільської (селищної, міської) ради об'єднаної територіальної громади.

09.02.2017 Верховною Радою України було прийнято Закон України № 1848-VIII «Про внесення змін до деяких законів України щодо статусу старости села, селища» (далі Закон №1848) [6]. Вказаний закон вніс у законодавство зміни з питань деталізації правового статусу старост (повноваження старости, територіальні межі діяльності, підстави та порядок дострокового припинення повноважень старости тощо) та старостинського округу. Відповідно до цього закону старостинський округ - частина території об'єднаної територіальної громади, утвореної відповідно до Закону України «Про добровільне об’єднання територіальних громад», на якій розташовані один або декілька населених пунктів (сіл, селищ), крім адміністративного центру об'єднаної територіальної громади, визначена сільською, селищною, міською радою з метою забезпечення представництва інтересів жителів такого населеного пункту (населених пунктів) старостою.

Сьогодні, як «нове дихання», з'являються додаткові можливості, нові інформаційні ресурси для посадовців місцевого самоврядування. Один із них - нове інформаційно-аналітичне видання для старост та органів місцевого самоврядування «Радник Старост» [7]. На шпальтах цього видання Я. Брусенцова, аналізуючи новий статус старости, звертає увагу на те, що старостинський округ у проектному вимірі мав дещо інший зміст. Зокрема, йдеться про те, що «в пояснювальній записці до першої редакції ще проекту Закону № 1848 законотворці передбачали, що межі старостинського округу мають збігатися з межами території юрисдикції рад тих громад, які об'єдналися. Говорячи більш простою мовою, межі старостинських округів повинні збігатися 3 межами територій колишніх територіальних громад у тому вигляді, у якому вони існували до об’єднання. А от зміна таких меж (знову ж таки, на думку законотворців) могла би здійснюватися сільською, селищною, міською радою об'єднаної громади лише з метою покращення умов для зв'язків старости з населенням. Нині, як бачимо, маємо взагалі іншу редакцію означеного поняття, яка містить лише єдину заборону щодо територіальності обрання старости: йдеться про адміністративний центр ОТГ. Більше того, законодавець одразу наділив місцеві ради правом на власний розсуд «нарізати» старостинські округи. На сайті «Децентралізація влади» [8] із цього приводу зазначається, що рада громади самостійно формує старостинські округи, встановлює їхню кількість та межі, чим запроваджує повсюдність інституту старост на території об'єднаної громади, що є гарантією захисту прав та інтересів жителів усіх сіл та селищ. При цьому на території населеного пункту, який є адміністративним центром об'єднаної громади, староста не обирається, отже, і старостинського округу там не буде» [9].

Вибори старости проводяться за мажоритарною системою відносної більшості в єдиному одномандатному виборчому окрузі, до якого входить територія одного або декількох населених 
пунктів (сіл, селищ), визначених сільською, селищною, міською радою об'єднаної територіальної громади з метою забезпечення представництва інтересів жителів такого населеного пункту (населених пунктів) старостою (старостинський округ).

Право голосу на виборах старости мають громадяни України, які відповідно до статті 70 Конституції України належать до відповідної об'єднаної сільської, селищної, міської територіальної громади та проживають на території відповідного села, селища (сіл, селищ) в межах відповідного старостинського округу. Про початок виборчого процесу перших виборів старости оголошує територіальна виборча комісія своїм рішенням. Офіційне оголошення перших місцевих виборів старости здійснюється відповідною територіальною виборчою комісією протягом п’яти днів із дня прийняття рішення про призначення перших виборів старости. Перші місцеві вибори призначаються не пізніше ніж за 70 днів до дня виборів, а виборчий процес розпочинається за 50 днів до дня перших місцевих виборів. Тобто рада об'єднаної громади сама визначає, коли проводити вибори старости. Граничних строків для прийняття цього рішення радою в законодавстві не прописано.

Чинне законодавство України наділяє правом місцеву раду об'єднаної територіальної громади, виходячи із власних організаційних, фінансових та матеріальних можливостей, визначати перелік сіл, селищ, у яких обирається староста. Частина території об'єднаної територіальної громади, на якій староста реалізовує свої права та виконує обов'язки, може складатись як із одного населеного пункту, так і з декількох, жителі яких і повинні мати право обирати відповідного старосту.

Слід зазначити, що до моменту вибору старости функції місцевого самоврядування виконувала особа, яка здійснювала повноваження сільського, селищного голови відповідної територіальної громади до об'єднання. І навіть після об'єднання територіальних громад до обрання на виборах старости ці функції має виконувати особа, що до цього моменту виконувала обов'язки голови відповідної ради. Саме це визначено в перехідних положеннях Закону України «Про добровільне об'єднання територіальних громад».

Може виникнути ситуація, коли депутат міської ради виявить бажання балотуватись на посаду старости. Але поєднувати ці види діяльності така особа не може, адже в разі обрання старостою має скласти повноваження депутата місцевої ради. Так, відповідно до ч. 1 ст. 89 Закону України «Про місцеві вибори» особа, обрана депутатом Верховної Ради Автономної Республіки Крим, обласної, районної, міської, районної в місті, сільської, селищної ради, сільським, селищним, міським головою, старостою, для ііі реєстрації, в разі наявності іншого представницького мандата, зобов'язана подати до територіальної виборчої комісії протягом 20 днів із дня офіційного оприлюднення результатів місцевих виборів копію зареєстрованої заяви про припинення дії іншого представницького мандата, поданої відповідно до Верховної Ради України, Верховної Ради Автономної Республіки Крим, обласної, районної, міської, районної в місті, сільської, селищної ради.

Зауважимо, що в законодавстві присутні окремі моменти, які потребують уваги та, можливо, корекції. Так, відповідно до змісту абз. 8 ст. 14 Закону про службу в органах місцевого самоврядування старостам, поряд із іншим і видами державних службовців, присвоюється шоста категорія (цій категорії відповідають 13, 12 і 11 ранги). Справа в тому, що раніше постановою КМУ від 26 жовтня 2001 року № 1441 «Про віднесення посад органів місцевого самоврядування до відповідних категорій посад» [10] було передбачено, що посада старости належить до п’ятої категорії посад ОМС (ій відповідає 11, 10 або 9 ранг). Нині з абз. 4 п. 1 постанови № 1441 виключено слово «староста», тобто віднині цей документ не встановлює категорію для старости. Наразі це питання регулюється виключно Законом України «Про службу в органах місцевого самоврядування» [11]. Такий «перехід» слід вважати змінами в організації виробництва і праці, що має свої особливості. Так, згідно зі ст. 32 КЗпП про зміну таких умов працівник має бути попереджений не пізніше ніж за 2 місяці. Протягом цих двох місяців за працівником зберігаються колишні умови оплати праці.

При цьому важливою гарантією $є$ те, що в разі, якщо посадова особа місцевого самоврядування обрана чи призначена на посаду нижчої категорії, за нею зберігається присвоєний ранг (ст. 15 Закону Украӥни «Про службу в органах місцевого самоврядування»). Таким чином, якщо старості раніше присвоєно ранг у межах п'ятої категорії посад, під час віднесення посади до шостої категорії ранг у нього не зменшується.

В осіб, що виконували обов'язки сільських, селищних, міських голів та секретарів рад, обраних територіальними громадами, що об'єдналися, повноваження завершуються в день набуття повноважень сільською, селищною, міською радою, обраною об'єднаною територіальною 
громадою. Тому може виникнути ситуація, коли ці особи вже не мають законних повноважень виконувати обов'язки сільських, селищних, міських голів та секретарів рад, а вибори старост ще не проведені. 3 огляду на це важливим правочинним рішенням є можливість покладання виконання обов'язків старости на конкретну людину на першій сесії ради ОТГ.

Із моменту призначення особи виконуючою обов'язки старости або призначення старости для цих осіб з'являються нові функціональні права та обов'язки, які відповідно до статті 14-1 Закону України «Про місцеве самоврядування в Україні» визначаються в Положенні про старосту, що затверджується сільською, селищною, міською радою відповідної об'єднаної територіальної громади. Таким чином, на першій сесії ОТГ має затверджуватись і Положення про старосту, що $є$ доволі проблематичним. О. Врублевський, експерт-консультант проекту DESPRO з питань діяльності старост та співробітництва територіальних громад, звертає увагу на те, що «староста має інтенсивні службові відносини з посадовими особами місцевого самоврядування та місцевих органів виконавчої влади. Вони можуть бути як успішними, так і напруженими» [12]. У разі, якщо такі відносини $€$ «напруженими», виникає правовий вакуум, який непросто заповнити непідготовленій особі.

Адже староста - це нерідко, хоча й авторитетна особа, якій довіряють у селі або селищі, але якій може бракувати досвіду та інструментів для вирішення елементарних поточних питань життєдіяльності громади. Староста - це посадова особа місцевого самоврядування, яка несе відповідальність за виконання покладених на неї функцій.

Неоднозначним питанням правового закріплення прав та обов'язків старости виявилось і питання щодо обов'язковості посадової інструкції для старости. Дійсно, не так просто знайти висококомпетентну особу в селі або селищі, належного віку та з відповідним рівнем освіти та компетенцій. Саме тому, очевидно, Міністерство соціальної політики України (далі - Мінсоцполітики) у листі від 05.09.2016 № 477/13/116-16 висловило «обережну» точку зору щодо кваліфікаційних вимог до старости та посадової інструкції. I хоча слід взяти до уваги, що листи Мінсоцполітики, як і інших міністерств, не є нормативно-правовими актами, вони мають лише інформаційний, роз'яснювальний та рекомендаційний характер, зміст цього листа Мінсоцполітики фокусує увагу на винятковості посади старости. Як відомо, посадова інструкція - це структурований документ, який має визначати організаційно-правовий статус працівника, його повноваження, завдання, обов'язки та права, вимоги щодо знань та кваліфікації, необхідних для забезпечення ефективної роботи працівника, а також його відповідальність.

Зокрема, до посади старости законами України не визначено кваліфікаційних вимог (рівень освіти, фах, стаж відповідної роботи) i, вирогідно, саме з цієї причини для цих працівників навіть не $є$ обов'язковими посадові інструкції, адже відповідно до Загальних положень Довідника кваліфікаційних характеристик професій працівників, які вміщено до Випуску 1 «Професії працівників, які є загальними для всіх видів економічної діяльності» (розділ 1 «Професії керівників, професіоналів, фахівців та технічних службовців»), затвердженого наказом Мінпраці від 29.12.2004 р. № 336, посадові інструкції складаються для працівників усіх посад, що передбачені в штатному розписі. Виняток можуть становити окремі посади керівників, правове положення яких визначено у Статуті (положенні) підприємства, установи, організації або відповідного підрозділу, де зазначено основні завдання, обов'язки, права і відповідальність за виконання покладених на них функцій. 3 огляду на вищенаведене Мінсоцполітики робить висновок, що Положення про старосту, затверджене в установленому порядку, згідно із яким староста діє як виборна посада, робить посаду старости винятковою.

На нашу думку, основні складові правового статусу старости мають бути визначені в Положенні про старосту, яке затверджується сільською, селищною, міською радою відповідної об'єднаної територіальної громади, а тому питання підготовки та затвердження посадової інструкції старости залишається на розсуд юридичної служби апарату сільської, селищної, міської рад. Слід зазначити, що основною вимогою до посади старости є його спроможність працювати на благо громади.

Як зазначалось вище, для кандидатів на посаду старости (в загальному порядку) не передбачено наявності спеціальної освіти або складання іспиту зі знання основ місцевого самоврядування, наявності практичного досвіду роботи на державній службі або на службі в органах місцевого самоврядування. Відсутні і вимоги до кандидатів щодо граничного віку та обов'язкового проживання на території територіальної громади.

Є допустимим, що ця особа не обов'язково повинна мати вищу освіту та стаж роботи, але принципово важливим $є$ бажання та здатність старости працювати для своєї громади, бути 
iї формальним лідером. Староста повинен продемонструвати стратегічне бачення розвитку села чи селища, бути хорошим комунікатором, бути доступним для мешканців села і водночас стати рушійною силою позитивних змін.

Тим не менше, частина функцій, що покладаються на старост, передбачає наявність спеціальної освіти. Так, для вчинення нотаріальних дій (до повноважень виконавчих органів сільських рад (посадових осіб місиевого самоврядування) відповідно до ст. 37 Закону Украӥни «Про нотаріат» віднесено вчинення таких нотаріальних дій: вжиття заходів щодо охорони спадкового майна, посвідчення заповітів (крім секретних), видача дублікатів посвідчених ними документів, засвідчення вірності копій (фотокопій) документів та виписок із них, засвідчення справжності підпису на документах, видача свідоцтва на право на спадщину, видача свідоцтва про право власності на частку у спільному майні подружжя в разі смерті одного з них), до посадової особи висуваються вимоги щодо наявності вищої юридичної освіти, досвіду роботи в галузі права не менше 3 років, проходження протягом року стажування у державній нотаріальній конторі або приватного нотаріуса, завершення навчання щодо роботи з Єдиними та державними реєстрами, що функціонують в системі Міністерства юстиції України, та складання іспиту зі спадкового права у порядку, встановленому Міністерством юстиції України.

Зауважимо, що нерідко старостами стають особи, які виконували обов'язки сільських, селищних голів. Ці особи традиційно більше приділяють увагу господарським питанням, меншою мірою працюють із документами. Ці функції виконували їхні секретарі. Тому і нині вони не поспішають покласти на себе додаткові обов'язки, а з ними і відповідальність.

У будь-якому випадку права та обов'язки старости мають бути конкретизовані та доступні для ознайомлення будь-яким мешканцем громади на он-лайн ресурсі органу місцевого самоврядування. Для складання як Положення про старосту, так і посадової інструкції старости доречним $є$ використати:

- Класифікатор професій ДК 003:2010, затверджений наказом Держспоживстандарту від 28.07.2010 № 327, з останніми змінами, затвердженими наказом Мінекономрозвитку від 10.08.2016 № 1328. Відповідно до цього Класифікатора професій посада «староста» 3 кодом 1229.3 належить до групи «Керівники апарату місцевих органів державної влади та місцевого самоврядування»;

- Довідник кваліфікаційних характеристик професій працівників, вміщених до Випуску 1 «рофесії працівників, які є загальними для всіх видів економічної діяльності» (розділ 1 «Професії керівників, професіоналів, фахівців та технічних службовців», затвердженого наказом Мінпраці від 29.12.2004 № 336 (далі - ДКХП);

- Статут об'єднаної територіальної громади;

- Локальні нормативні акти ради ОТГ та виконкому, якими, наприклад, було уповноважено старосту на здійснення окремих повноважень, визначено відповідні правила внутрішнього трудового розпорядку та ін.

Висновок. На наш погляд, до посади старости слід в обов'язковому порядку висувати певні вимоги. Особа, яка не проживає на території територіальної громади (наявність зареєстрованого місця проживання на території населеного пункту, віднесеного до одномандатного виборчого округу для проведення виборів старости) не може повністю знати специфіку роботи, мешканців тощо, що в майбутньому може ускладнити виконання професійних повноважень. Окрім того, вважаємо доцільним для осіб, які виявили бажання зайняти посаду старости, проведення попередніх он-лайн курсів за напрямом муніципального управління, складання іспиту щодо обізнаності із правовою регламентацією питання. Інші вимоги, наприклад, щодо спеціальної освіти, можуть бути передбачені в Положенні про старосту.

\section{Список використаних джерел:}

1. Кабмін пропонує Раді запровадити посаду сільського старости. URL : https://www.rbc. ua/ukr/news/kabmin-predlagaet-rade-vvesti-dolzhnost-selskogo-starosty-16062014163800 (дата звернення: 20.01.2019).

2. Дробуш І. Староста як нова організаційна форма місцевого самоврядування та його участь у реалізації соціальної функції. Науковий вісник Міжнародного гуманітарного університету. Сер. Юриспруденція. 2014. № 10 C. 49. URL : http://vestnik-pravo.mgu.od.ua/archive/ juspradenc10-2/part_1/16.pdf (дата звернення: 20.01.2019).

3. Ганущак Ю. Реформа територіальної організації влади / Швейцарсько-український проект «Підтримка децентралізації в Україні-DESPRO». Київ : TOB «Софія-А», 2013. С. 60. 
4. Старости в об'єднаних громадах. URL : https://decentralization.gov.ua/starosta (дата звернення: 20.01.2019).

5. Коновалов В. Визначити правові засади діяльності старости. URL: https://decentralization. gov.ua/starosta (дата звернення: 20.01.2019).

6. Про внесення змін до деяких законів України щодо статусу старости села, селища: Закон України 9 лютого 2017 року № 1848-VIII. URL : https://zakon.rada.gov.ua/laws/show/1848-19/ print (дата звернення: 20.01.2019).

7. Радник Старости. URL : https://old.decentralization.gov.ua/pics/attachments/radnik starosti 0117 u.pdf (дата звернення: 20.01.2019).

$\overline{8}$. Старости в селах об'єднаних громад: що змінює новий закон. URL : http://decentralization. gov.ua/news/item/id/4433 (дата звернення: 20.01.2019).

9. Брусенцова Я. Староста, його статус, повноваження: вивчаємо знову. URL : https://i.factor.ua/ukr/journals/rs/2017/april/issue-1/article-32913.html (дата звернення: 20.01.2019).

10. Про віднесення посад органів місцевого самоврядування до відповідних категорій: Постанова КМУ від 26 жовтня 2001 року № 1441 / Кабінет Міністрів України. URL : https://zakon. rada.gov.ua/laws/show/1441-2001-\%D0\%BF (дата звернення: 20.01.2019).

11. Про службу в органах місцевого самоврядування : Закон України від 7 червня 2001 року № 2493-III / Верховна Рада України. URL : https://zakon.rada.gov.ua/laws/show/2493-14/ print (дата звернення: 20.01.2019).

12. Чи потрібно розробляти посадову інструкцію старости: роз'яснення та поради фахівця. URL : https://decentralization (дата звернення: 20.01.2019).

УДК 342:001.5(091):165.321+342.4

DOI https://doi.org/10.32844/2618-1258.2019.3-2.9

ЯкИМОВИч Я.В.

\section{СИСТЕМА ВИТОКІВ АТРОПОЦЕТРИЗМУ У ФОРМУВАННІ СУЧАСНОГО КОНСТИТУЦІОНАЛІЗМУ ДЕРЖАВНОЇ ВЛАДИ}

Явище антопоцентризму в державій владі існувало завжди та, починаючи від перших державовладних утворень, виражалося в різноманітних поглядах, концепціях, підходах. У цьогочасному суспільстві з розвитком демократичних форм державного режиму та інтенсивністю державотворчих процесів усе більшого значення набувають знання, вміння, навички, досвід (людський чинник) самого суб'єкта владних повноважень, що і зумовлює актуальність зазначеного явища. Незважаючи на це, наведена тематика найбільше розробляється в соціології права, політології, філософії права, а також в окремих підходах адміністративного права. У конституційному ж праві цей напрямок досліджений тільки окремими поглядами, викладеними в дисертаціях, та загальними думками щодо суб'єктів конституційно-правових відносин. Проте явище людського чинника повинно бути вивчене на фундаменті основного закону в першу чергу, оскільки саме від вимог конституційної дієздатності, прав, дискреційних повноважень, обов'язків та інших елементів конституційно-правового статусу воно отримує свої витоки і можливість бути реалізованим та впливати на державотворчі процеси.

У цій статті антропоцентризм досліджується з точки зору чотирьох позицій та п’яти критеріїв. До основних позицій належать історичний, емпіричний (практика державотворчих подій та процесів), доктринально-правовий та нормативно-конституційний підходи. Комплексний характер дозволяє відобразити перехід явища з однієї позиції в іншу, ілюструючи тенденційність розвитку. П’ять критеріїв

(C) ЯКИМОВИЧ Я.В. - аспірант кафедри конституційного права та порівняльного правознавства (Ужгородський національний університет) 